\title{
Changes in Drought Conditions in Poland over the Past 60 Years Evaluated by the Standardized Precipitation-Evapotranspiration Index
}

\author{
Urszula SOMOROWSKA \\ University of Warsaw, Faculty of Geography and Regional Studies, \\ Warsaw, Poland; e-mail: usomorow@uw.edu.pl
}

\begin{abstract}
This paper investigates the variability of drought conditions in Poland in the years 1956-2015 with the use of the Standardized Precipitation-Evapotranspiration Index (SPEI). The study provides a new insight into the phenomenon of the past expansion of the drought-affected area as well as evidence of drying trends in a spatiotemporal context. 3-month, 6-month, and 12-month SPEI were considered, representing drought conditions relevant to agriculture and hydrology. The analysis demonstrates that the spatial extent of droughts shows a broad variability. The annual mean of the percentage of the area under drought has witnessed an increase for all three SPEI timescales. This also pertains to the mean area affected by drought over the growing season (April-September). A decreasing trend in the SPEI values indicates an increase in the severity of droughts over the 60-year period in question in an area extending from the south-west to the central part of Poland.
\end{abstract}

Key words: drought conditions, SPEI, changes, Poland.

\section{INTRODUCTION}

In recent decades an increase in the frequency and severity of summer droughts is reported to be an emerging issue globally (Kundzewicz 2008). This also concerns Poland. Prolonged dry and hot periods in the summer

Ownership: Institute of Geophysics, Polish Academy of Sciences;

(c) 2016 Somorowska. This is an open access article distributed under the Creative Commons Attribution-NonCommercial-NoDerivs license,

http://creativecommons.org/licenses/by-nc-nd/3.0/. 
lead to reduced recharges of soil moisture and groundwater, resulting as a consequence in long-lasting low flows and a deficit in the water balance (Tokarczyk 2013, Kędziora et al. 2014). Since the 1980s, Poland has experienced significant summer droughts. The period from 1982 to 2006 was marked by multiple years of extreme heat and precipitation shortfalls, resulting in widespread droughts (Labędzki 2007, Lorenc et al. 2008). In a warming climate in Poland, an increase in the number of extremely warm days in a year and an increase in the maximum number of consecutive hot days have been observed for the period 1951-2010 (Graczyk and Kundzewicz 2014). Summer deficit does not show any statistically significant trend (Wibig 2012). As the summer precipitation deficit is projected to increase considerably in the future, Poland might face a high risk of water shortages in the next decades (Szwed et al. 2010).

Noteworthy is that an extremely hot and dry summer occurred in Poland in 2015. Significant dry conditions occurred in August across the whole country, from the Silesian Lowland, through the Wielkopolska Lowland and Mazovian Lowland to the Lublin Upland and Podlasie Lowland (IUNG-PIB 2015). Over the majority of the country, rainfall in August ranged from 10 to $30 \%$ of the long-term norm. As a consequence, discharge from the Vistula basin in August constituted only $42.5 \%$ of the long-term mean, and from the Oder Basin 35\% (IMGW 2015). The River Vistula reached a new low record which was the lowest stage since records began in the eighteenth century. Simultaneously, in many rivers the stages (and discharges) fell to the lowest values, reaching the absolute minimum registered since the 1950s, especially in August and September (IMGW 2015).

As there is evidence of several drought events in Poland during the last decades, a new assessment of drought trends over the past 60 years seems to be a challenging issue. It might give new insights into an expansion of the area affected by drought in the past, and into the evidence for drought trends in a spatiotemporal context. A range of different single or combined indicators is already used to detect and monitor droughts (e.g., Zargar et al. 2011, Łabędzki and Bąk 2014, Ziese et al. 2014). The most commonly used is the Standardized Precipitation Index (WMO 2012), also used in drought studies in Poland (e.g., Osuch et al. 2015, Radzka 2015). In addition to the Standardized Precipitation Index (SPI), its newer variant, called the Standardized Climatic Water Balance (SCWB), was introduced in Poland by Łabędzki and Bąk (2004) and used for an assessment of regional droughts. The difference between precipitation and Penman-Monteith reference evapotranspiration was utilized. More recently proposed is the Standardized PrecipitationEvapotranspiration Index (SPEI) which is based on the same concept, using the difference between precipitation and potential evapotranspiration (Vicente-Serrano et al. 2010). It was designed as an improved drought index for 
studies of the effect of warming on drought severity (Begueria et al. 2014). The advantage of the SPEI (alternatively called the SCWB) over the SPI is that it is based not only on precipitation, but includes the component of potential evapotranspiration (PET). It normalizes anomalies in accumulated climatic water balance, calculated as the difference between precipitation and potential evapotranspiration. Different evapotranspiration equations might be applied in the SPEI calculation (Stagge et al. 2014), among which there is a Thornthwaite equation (Thornthwaite 1948), based on air temperature with an adjustment being made for the number of daylight hours. This method, requiring only limited data, was applied in the original SPEI methodology proposed by Vicente-Serrano et al. (2010) and is used in the SPEI Global Drought Monitor (Begueria et al. 2010). The choice of a more sophisticated PET method is limited by higher input requirements. Previous studies proved that the largest differences between SPEI calculated using different PET equations occur during the winter and spring, whereas the best agreement occurs during the summer (Stagge et al. 2014). Thus it might justify the choice of SPEI data from the Global Drought Monitor as first guess data, to consider and investigate, especially the summer droughts. Another SPEI data, the SPEIbase, is based on the FAO-56 Penman-Monteith estimation but at the moment it covers the temporal range up to December 2014 only. In Poland, the SPEI based on the Thornthwaite equation was investigated by Wibig, using data from 18 synoptic stations for the years 19512006 (Wibig 2012). In the context of the recent drought that occurred in 2015 , further research on an expanded temporal window might give new evidence of drought severity trends, proving or contradicting previous findings.

This study analyzes the changes in the areas under drought in Poland over the past sixty years and gives an insight into drying trends evaluated by the SPEI over the long-term period, chosen here as 1956-2015.

\section{DATA AND METHODS}

The SPEI data used in this study were acquired from the Global Drought Monitor database, in which the PET is calculated by the Thornthwaite equation (Begueria et al. 2010). Climate data used for the SPEI calculation include air temperature data from the station observation-based global land monthly mean surface air temperature dataset at $0.5^{\circ}$ spatial resolution, developed at the Climate Prediction Center, National Centers for Environmental Prediction in the US (Fan and van den Dool 2008). Additionally, monthly precipitation sums data were acquired for the SPEI calculation from the Global Precipitation Climatology Center (GPCC). The "first guess" monthly land-surface precipitation product at $1.0^{\circ}$ spatial resolution (Ziese et al. 2011), interpolated to a resolution of $0.5^{\circ}$, is applied. The SPEI time series over Poland have been retrieved at 196 grid cells (Fig. 1) for the period 


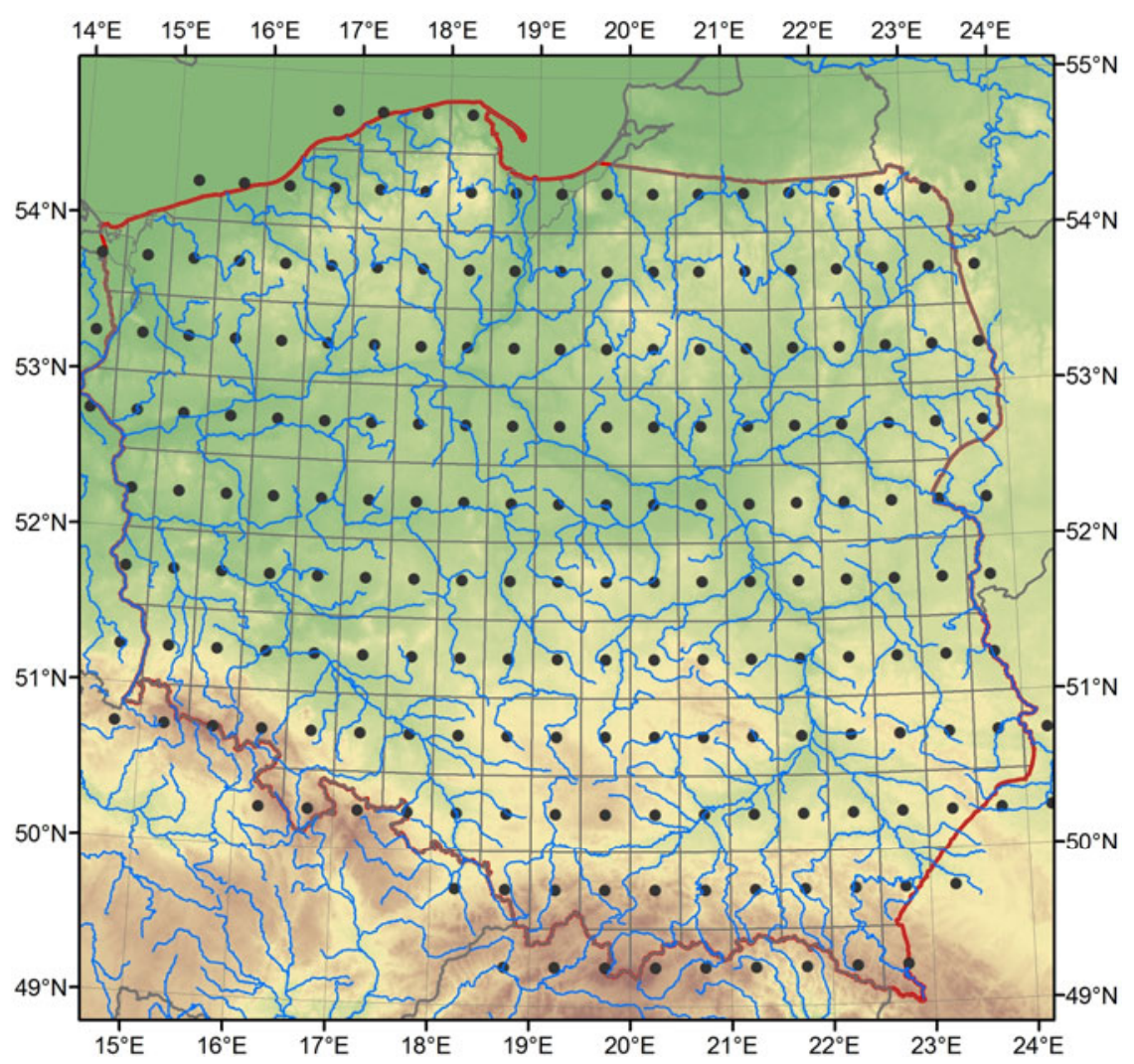

Fig. 1. Spatial distribution of grid cells of the SPEI Global Drought Monitor covering the territory of Poland.

January 1956 up to December 2015. Data were downloaded from online resources (http://sac.csic.es/spei). The dataset at a $0.5^{\circ}$ spatial resolution includes different time-scales between 1 and 48 months. In this study, three time scales, 3, 6, and 12 months, have been selected, representing dryness/ wetness conditions relevant to agriculture and hydrology (WMO 2012). The SPEI-3 represents cumulative moisture conditions for the 3-month period. For example, a 3-month SPEI at the end of June represents cumulative moisture conditions for April-May-June. Similarly, the SPEI-6 and the SPEI-12 represent cumulative wetness conditions for the 6-month and 12-month periods. Positive values of the SPEI indicate wetness conditions wetter than average, whilst negative values indicate conditions drier than average. A drought is considered to occur when the SPEI value is less than or equal to -1 . Three different drought categories were distinguished according to the SPEI value: moderate (D1), severe (D2), and extreme (D3) events (Table 1). 
Table 1

Dryness/wetness categories according to the SPEI values

\begin{tabular}{|r|l|}
\hline SPEI value & Dryness/wetness category \\
\hline$\leq-2.00$ & Extreme drought (D3) \\
-1.99 to -1.50 & Severe drought (D2) \\
-1.49 to -1.00 & Moderate drought (D1) \\
-0.99 to 0.99 & Near normal \\
1.00 to 1.49 & Moderately wet \\
1.50 to 1.99 & Severely wet \\
$\geq 2.00$ & Extremely wet \\
\hline
\end{tabular}

Area affected by 3-month and 12-month droughts of three different categories at a country level was determined by summing up the area of grid cells (Fig. 1). Based on that, the most widespread drought events were detected over the years 1956-2015. Averaging monthly values of percent of area under drought in each year, the annual mean was calculated and checked for a trend or tendency. Similarly, seasonal means for the winter half (November-April) of the year and for the summer half (May-October), and for the growing season (April-September), were calculated and tested for any changes.

Following this, time series of SPEI-3 and SPEI-12 at each grid cell were checked for each month, whether or not there is a long-term trend. Independently, a long-term trend analysis was conducted for the SPEI-3 and SPEI-12 averaged over the growing season (April-September). Additionally, a long-term trend analysis was conducted for the SPEI-6, based on the time series at each grid cell for September, ending the 6-month growing season. The non-parametric rank-based Mann-Kendall test was applied to detect drying or wetting trends of the SPEI. It is one of the most widely used methods for hydro-meteorological time series trend detection (Radziejewski and Kundzewicz 2004a, Machiwal and Jha 2012) applied formerly, among others, in the trend analysis of drought indices (e.g., Wibig 2012, Damberg and AghaKouchak 2014, Potop et al. 2014). The HYDROSPECT software (Radziejewski and Kundzewicz 2004b) was used to calculate the MannKendall test statistic ( $Z$ ), and the statistical significance. Negative values of $Z$ indicate decreasing trends in the SPEI (drying trend) whilst positive $Z$ values characterize increasing trends (wetting trends). Trends were tested at the threshold values of significance level. Significance levels of 99.9, 99, 95, and $90 \%$ correspond to $|Z|$ values of $3.290,2.575,1.960$, and 1.645 . The Kendall-Theil robust line was used to quantify the magnitude of the identified trends (Theil 1950, Helsel and Hirsch 2002). The Kendall-Theil method 
was chosen as an alternative to simple linear regression because it requires no assumption of the data distribution and is less sensitive to outliers. It has been applied in many hydrological and environmental studies (e.g., Wang et al. 2014, Zhang et al. 2015).

\section{RESULTS AND DISCUSSION}

\subsection{Area under drought}

Figures 2 and 3 provide an insight into the temporal evolution of the percentage of the country area under drought, evaluated respectively by SPEI-3 and SPEI-12. The most widespread 3-month extreme summer drought events (Fig. 2a) affected 46\% of the country in April 1974, 43\% in August 1992, and $47 \%$ in August 2015, whilst the most extensive winter drought covered $43 \%$ of the territory in March 1989, 65\% in January 1997, and 39\% in November 2011. Considering the area under extreme (D3) and severe (D2) droughts together (Fig. 2c), the most widespread summer events occurred in April 1974 (78\%), August 1992 (87\%), and August 2015 (70\%), whilst in the winter half - they were in January 1997 (91\%), March 1989 (88\%), and November 2011 (73\%). The percentage of area under drought conditions of D1, D2, and D3 together, exceeding $90 \%$ of the country territory, occurred in December 1957, March 1972, April 1974, November 1982, March 1989, August 1992, January-February 1997, November 2005, and August-September 2015. The year 1959 was also relatively dry, with the peak in May, when $89 \%$ of the country was in drought. In 47 months of the period from January 1956 until December 2015, the percentage of area under the 3month drought $(\mathrm{SPEI} \leq-1)$ was larger than $70 \%$, comprising both droughts appearing in the summer and winter halves of the year.

The most widespread extreme 12-month drought (Fig. 3a) occurred in August 2015 (44\%), September 2015 (41\%), and October 2015 (28\%). The occurrence of drought in a sequence of months shows its persistence. A relatively large area was detected in the sequential months from May till September 1983, covering an area of $12-25 \%$ of the country's territory. Considering the area under drought conditions D3 and D2 together (SPEI $\leq$ -1.5 ), such a sequential occurrence of dry months took place over the whole period of analysis (Fig. 3c). However, the widest drought occurred again in a sequence of months in 2015, increasing from April (13\%) till August (83\%), and then decreasing from September (75\%), through October (63\%) till November (36\%). The area under drought conditions D1, D2, and D3 together (SPEI $\leq-1)$ was largest in 2015 (Fig. 3e). A sequence of dry months covering a large area of the country occurred already in September 2014 and lasted through the entire year 2015. The most widespread drought lasted from April 2015 (42\%) till August and September 2015 (98\%). Such sequences of 


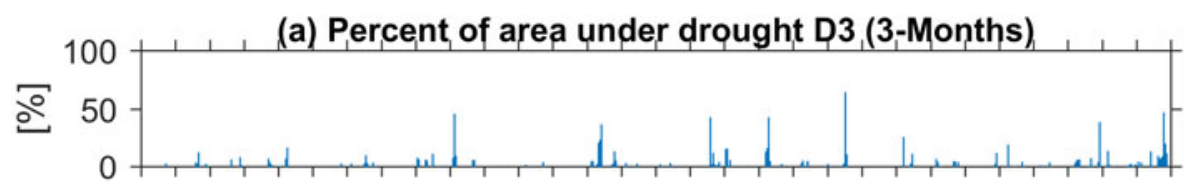

$\omega \infty$ 업

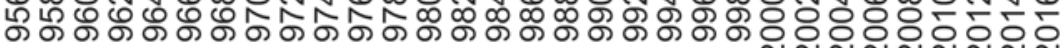

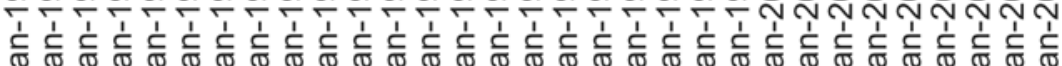

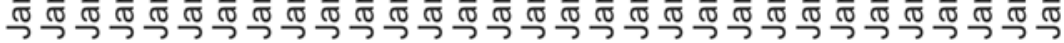
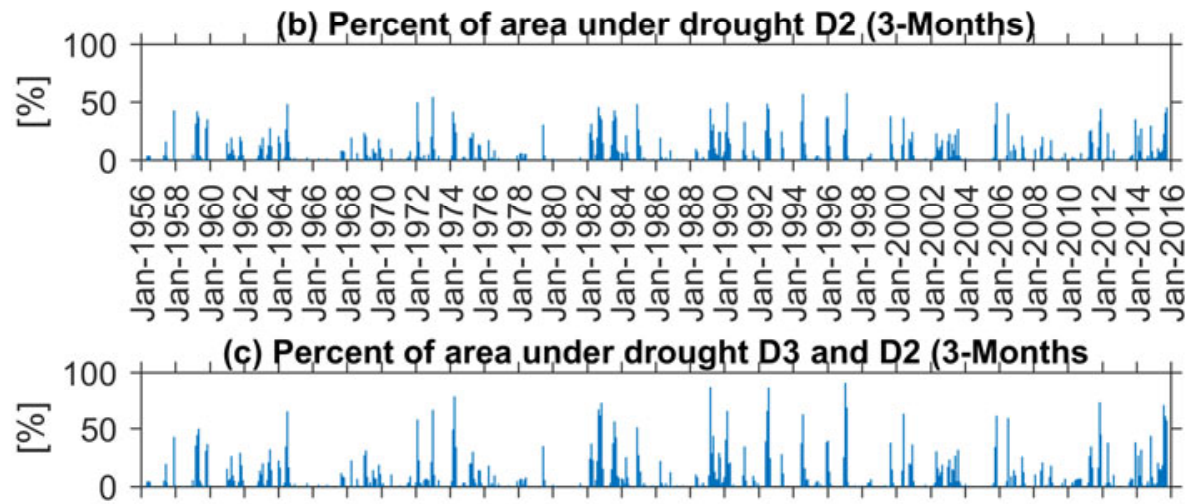

అ

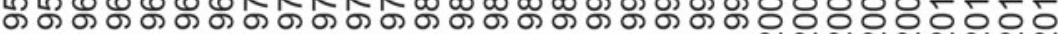
FTFF F F F F F T T T F T N N N N N N N

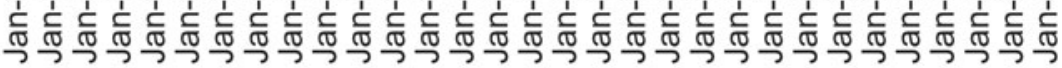
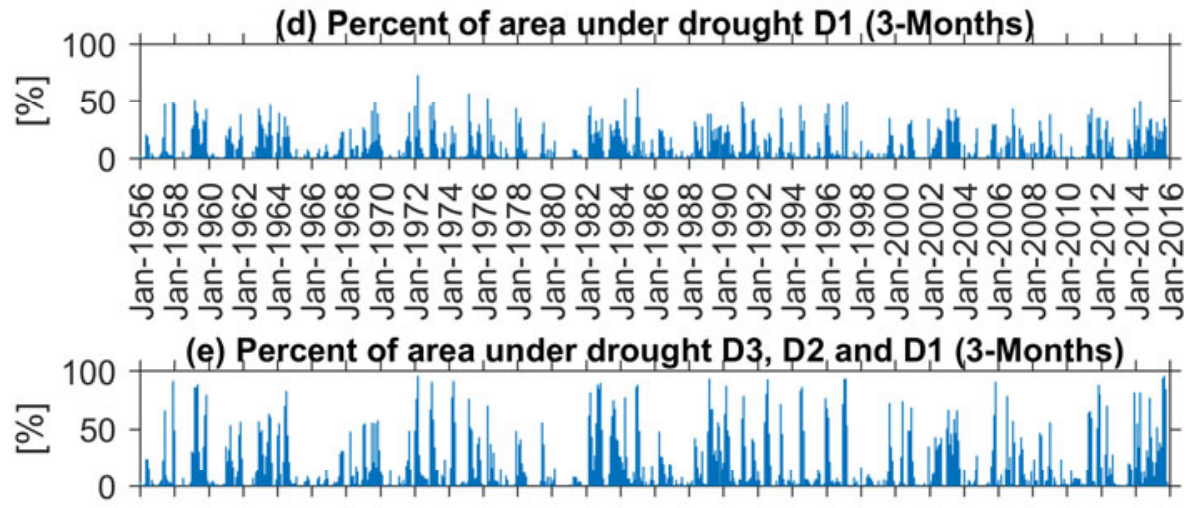

$\omega \infty$ 에 Ю の

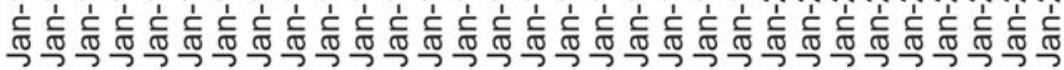

Fig. 2. Percent of area under the 3-month drought in the period 1956-2015: D3 (a), D2 (b), D3 and D2 (c), D1(d), and D3, D2 and D1 (e). 


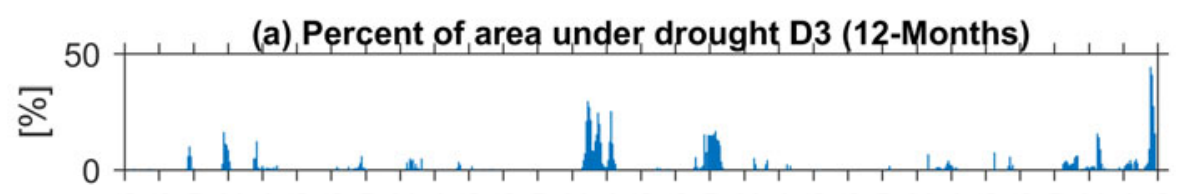

ம

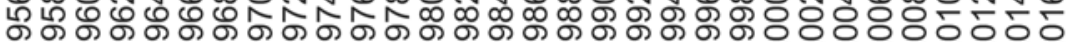

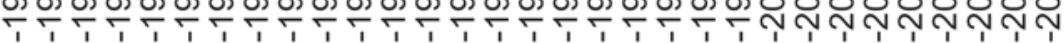

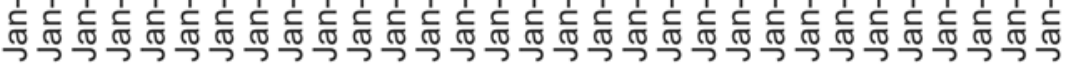

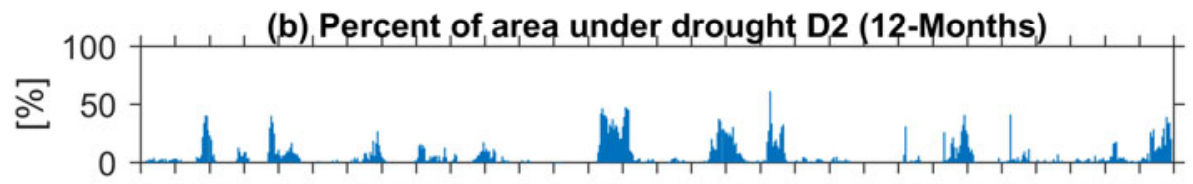

అ ద ద ब

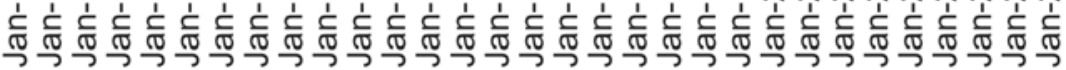

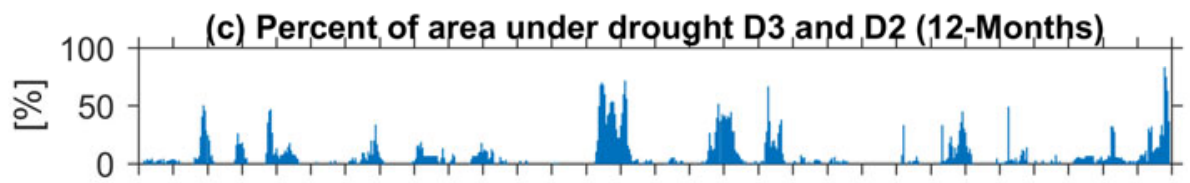

m

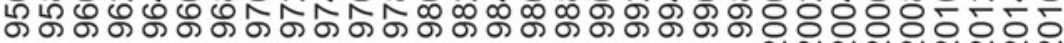

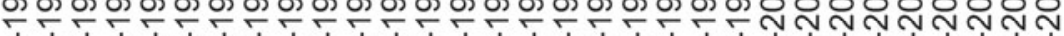

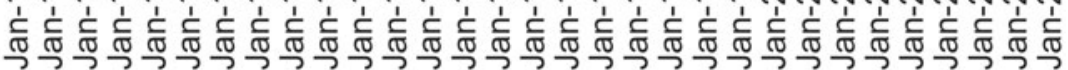
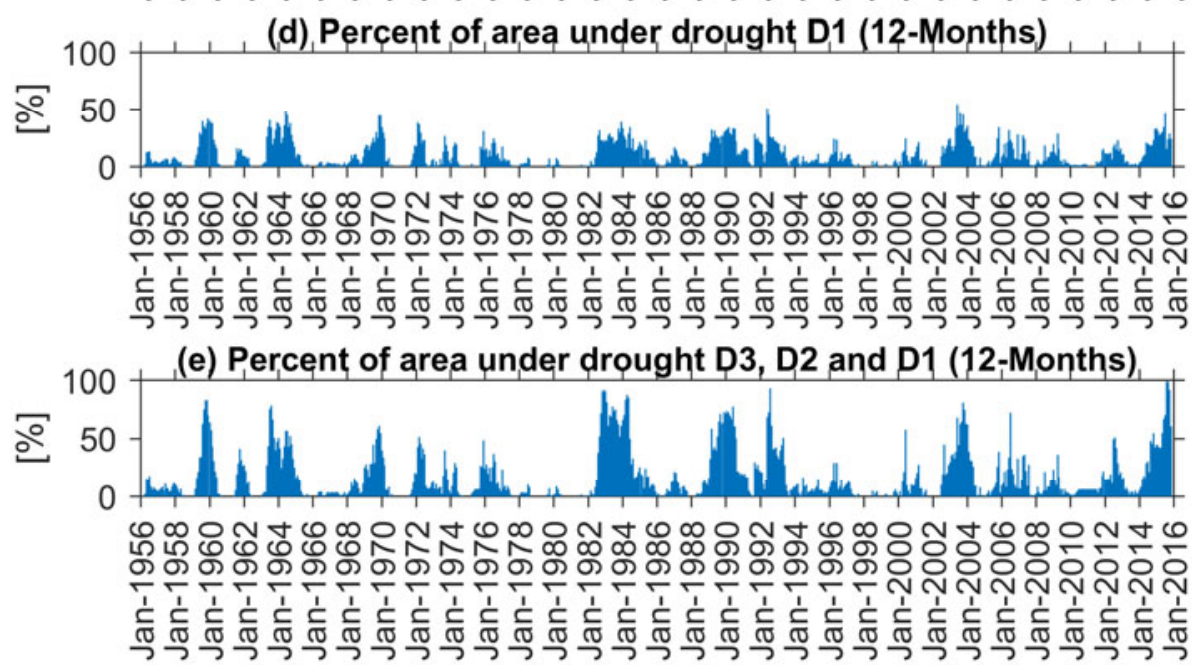

Fig. 3. Percent of area under the 12-month drought in the period 1956-2015: D3 (a), D2 (b), D3 and D2 (c), D1(d), and D3, D2 and D1 (e). 
dry months (SPEI $\leq-1$ ) occurred also in the past; the longest and the most widespread events took place in 1959-1960, 1963-1965, 1969, 1972-1974, 1976, 1982-1984, 1988-1990, 1992-1993, 2002-2003, and 2006.

The results show that large inter-annual variability in the area under drought exists. The annual mean of the percentage of area under drought, calculated by the Kendall-Theil robust line method and tested for significance by the Mann-Kendall test, increased in the years 1956-2015, with a change of $0.087 \% \cdot \mathrm{yr}^{-1}\left(270 \mathrm{~km}^{2} \cdot \mathrm{yr}^{-1}\right)$ for the 3-month droughts, and $0.052 \% \cdot \mathrm{yr}^{-1}\left(162 \mathrm{~km}^{2} \cdot \mathrm{a}^{-1}\right)$ for the 12-month droughts (Table 2). The longterm series of mean areas affected by drought over the growing season (April-September) show an increase with a rate of $0.105 \% \cdot \mathrm{yr}^{-1}\left(328 \mathrm{~km}^{2} \cdot \mathrm{yr}^{-1}\right)$ and $0.064 \% \cdot \mathrm{yr}^{-1}\left(200 \mathrm{~km}^{2} \cdot \mathrm{yr}^{-1}\right)$, respectively, for the 3-month and 12-month droughts. Much lower is an increase of the area under 6-month droughts appearing in the growing season, calculated both as a 6-month mean and for September only; it is within the range of $144-178 \mathrm{~km}^{2} \cdot \mathrm{yr}^{-1}$ (Table 2). It is worth noting that the highest rate of increase concerns the area under the

Table 2

Summary statistics of changes of drought area in Poland in the years 1956-2015

\begin{tabular}{|l|c|c|c|c|}
\hline $\begin{array}{l}\text { Time series: } \\
\text { Year }\end{array} \begin{array}{l}\text { Season } \\
\text { Month }\end{array}$ & $\begin{array}{c}|c| \\
\text { Test statistic } \\
Z\end{array}$ & $\begin{array}{c}\text { Significance } \\
\text { level [\%] }\end{array}$ & $\begin{array}{c}\text { Area percent } \\
{\left[\% \cdot \mathrm{yr}^{-1}\right]}\end{array}$ & $\begin{array}{c}\text { Area } \\
{\left[\mathrm{km}^{2} \cdot \mathrm{yr}^{-1}\right]}\end{array}$ \\
\hline 3-month droughts (D3, D2, and D1) \\
\hline Year & 0.969 & 67 & 0.087 & 270 \\
November-April & 0.625 & 47 & 0.035 & 110 \\
May-October & 1.352 & 82 & 0.117 & 367 \\
April-September & 1.276 & 80 & 0.105 & 328 \\
\hline 6-month droughts (D3, D2, and D1) & & \\
\hline Year & 0.944 & 65 & 0.077 & 241 \\
November-April & 1.225 & 78 & 0.087 & 272 \\
May-October & 0.680 & 51 & 0.043 & 136 \\
April-September & 0.561 & 43 & 0.046 & 144 \\
M09 & 1.050 & 71 & 0.057 & 178 \\
\hline 12-month droughts (D3, D2, and D1) & & \\
\hline Year & 0.829 & 59 & 0.052 & 162 \\
November-April & 0.612 & 46 & 0.045 & 141 \\
May-October & 1.033 & 70 & 0.079 & 219 \\
April-September & 0.944 & 65 & 0.064 & 200 \\
\hline
\end{tabular}


3 -month drought in the summer season (May-October) and is $0.117 \% \cdot \mathrm{yr}^{-1}$ $\left(367 \mathrm{~km}^{2} \cdot \mathrm{yr}^{-1}\right)$.

The drought conditions over Poland, detected in this study, refer to the most relevant European drought events evaluated by the combined indicators, reported recently by Spinoni et al. (2015). Among the list of $22 \mathrm{big} \mathrm{Eu-}$ ropean multi-region drought events that occurred from 1950 until 2011, ten of them concerned central and eastern Europe and were reflected also in Poland. The confirmed occurrence of such widespread droughts, marked also in Poland, concerns the years 1959, 1964, 1972-1974, 1976, 1983, 1992, 19961997, 2003, 2006, and 2011.

\subsection{Changes in the SPEI over an entire year}

In order to check if there is a trend in the SPEI values, 60-element series of singular SPEI-3 and SPEI-12 values were prepared for each grid cell, for each month. Then, the Mann-Kendall test was applied. Results are presented in Figs. 4 and 5. In the SPEI-3 monthly series (Fig. 4), a statistically significant trend occurred in many grid cells in the months April-October, covering $25 \%$ of the country's territory in April and 21\% in October (Table 3).

Table 3

Percent of the country area with drying trend and drying signals

\begin{tabular}{|l|c|c|c|c|}
\hline \multirow{3}{*}{ Month } & \multicolumn{4}{|c|}{ Percent of area [\%] } \\
\cline { 2 - 5 } & \multicolumn{3}{|c|}{3 -month SPEI } & \multicolumn{2}{|c|}{12 -month SPEI } \\
\cline { 2 - 5 } & $\begin{array}{c}\text { Drying } \\
\text { trend }\end{array}$ & $\begin{array}{c}\text { Drying } \\
\text { signal }\end{array}$ & $\begin{array}{c}\text { Drying } \\
\text { trend }\end{array}$ & $\begin{array}{c}\text { Drying } \\
\text { signal }\end{array}$ \\
\hline January & 7 & 38 & 18 & 45 \\
February & 3 & 18 & 19 & 47 \\
March & 0 & 6 & 18 & 46 \\
April & 25 & 44 & 18 & 46 \\
May & 13 & 32 & 23 & 44 \\
June & 16 & 43 & 19 & 43 \\
July & 6 & 30 & 23 & 49 \\
August & 17 & 62 & 33 & 64 \\
September & 13 & 56 & 32 & 63 \\
October & 21 & 58 & 30 & 56 \\
November & 7 & 40 & 29 & 57 \\
December & 13 & 65 & 23 & 52 \\
\hline
\end{tabular}

Explanations: Drying trend is assumed to occur for the test statistic of the Mann-Kendall test $Z$ values $\leq-1.645$. Drying signal is assumed to occur for the rate of change of the SPEI values $\leq-0.005 \mathrm{yr}^{-1}$, calculated as a slope of the Kendall-Theil robust line. 
a)

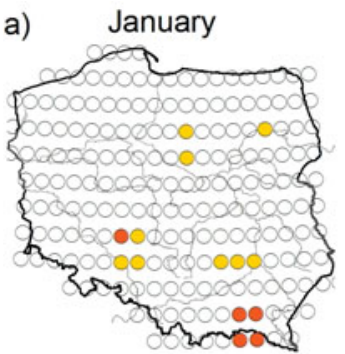

d)

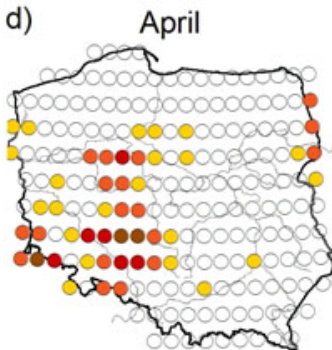

g)

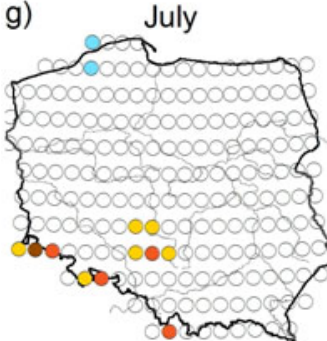

j)

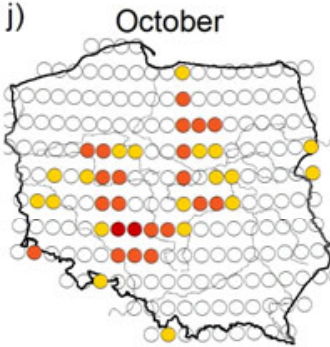

b) February

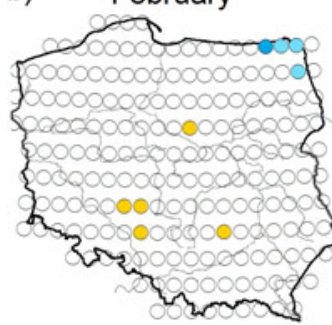

e)

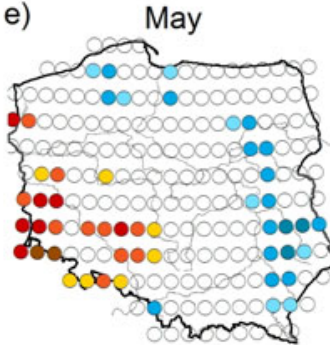

h)

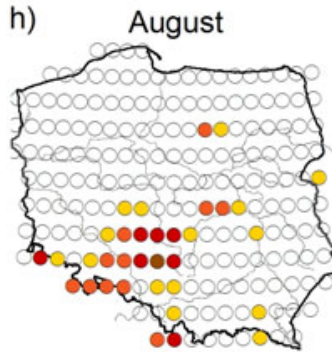

k)

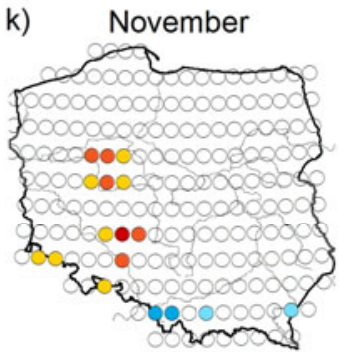

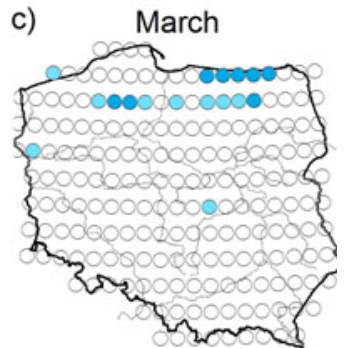

f)

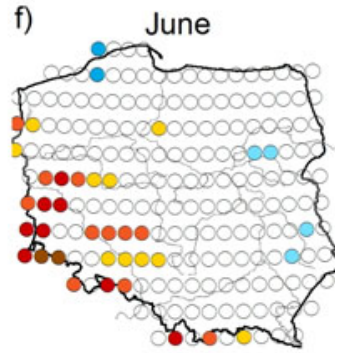

i) September

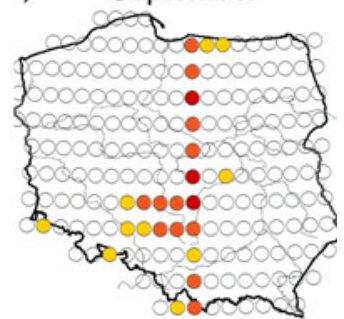

I) December

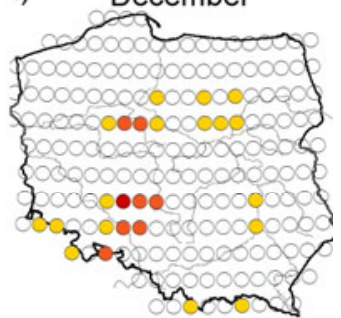

Test Statistic / Significance level (\%)

- $<=-3.290 / 99.9 \%$ - $(-1.645-1.645) /$ not significant

- $(-3.290--2.575] / 99 \%$

- $[1.645-1.960) / 90 \%$

- $(-2.575--1.960] / 95 \%$

- $[1.960-2.575) / 95 \%$

- $(-1.956--1.645] / 90 \%$

- $[2.575-3.290) / 99 \%$

Fig. 4. Mann-Kendall test results of trend detection over Poland at the 90, 95, 99, and $99.9 \%$ significance levels for the SPEI-3 monthly series. Yellow, red and brown circles indicate decreasing trend in SPEI values, blue circles - increasing, whereas blank one - no trend detected. 

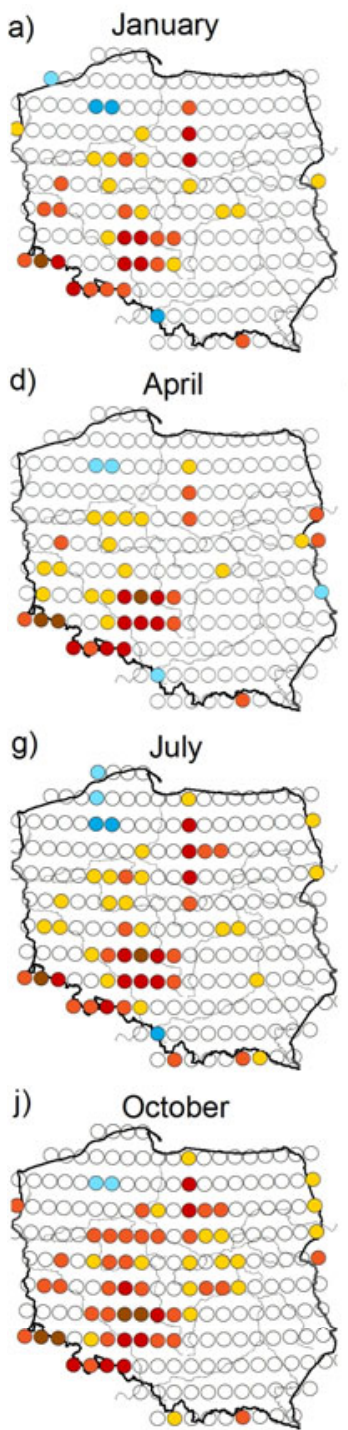
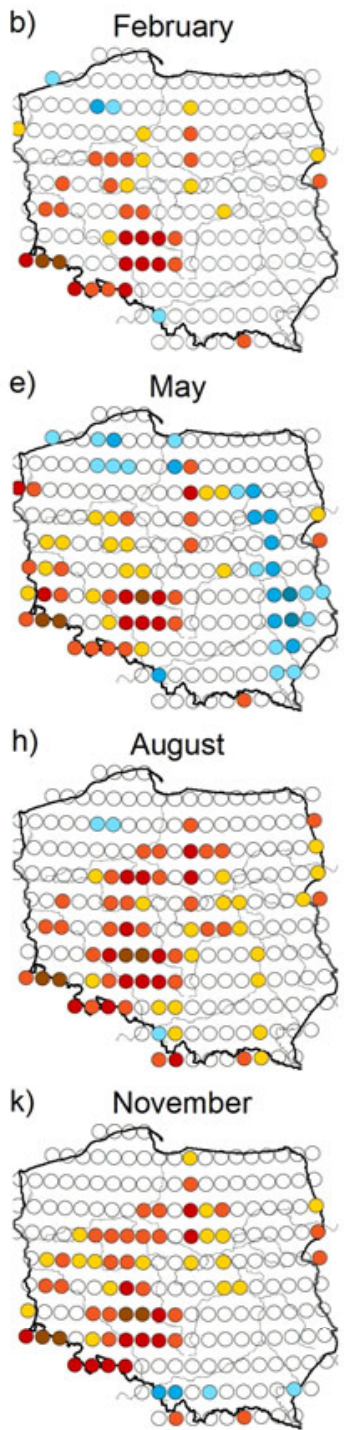
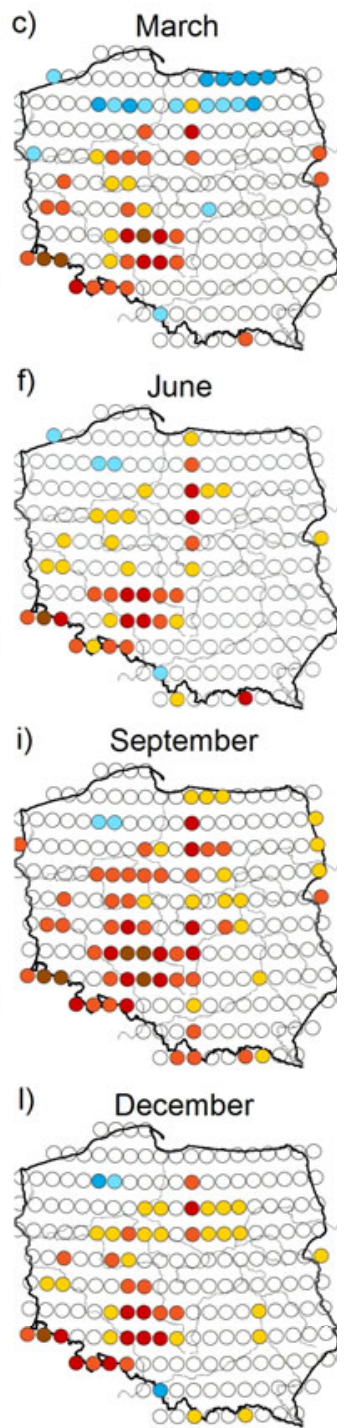

Test Statistic / Significance level (\%)
- $<=-3.290 / 99.9 \%$
$(-1.645-1.645) /$ not significant
- $\quad(-3.290--2.575] / 99 \%$
- $[1.645-1.960) / 90 \%$
- $(-2.575--1.960] / 95 \%$
- $[1.960-2.575) / 95 \%$
- $(-1.960--1.645] / 90 \%$
- $[2.575-3.290) / 99 \%$

Fig. 5. Mann-Kendall test results of trend detection over Poland at the 90, 95, 99, and $99.9 \%$ significance levels for the SPEI-12 monthly series. Yellow, red and brown circles indicate decreasing trend in SPEI values, blue circles - increasing, whereas blank one - no trend detected. 


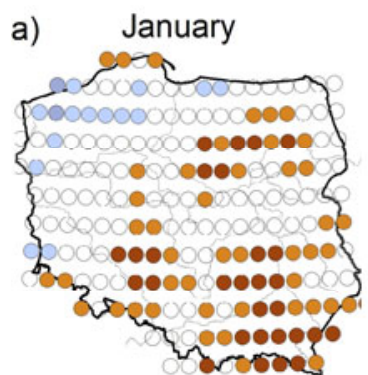

d)

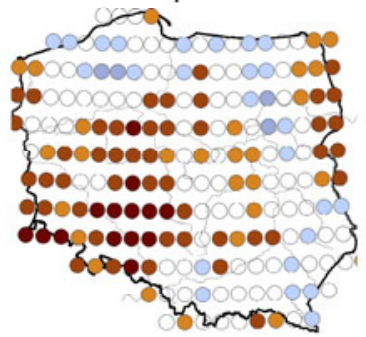

g)

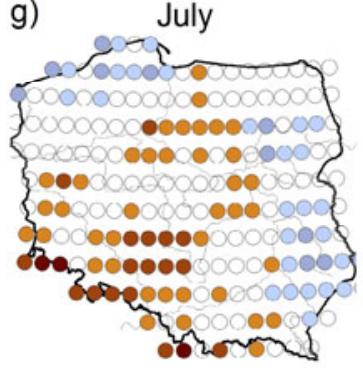

j)

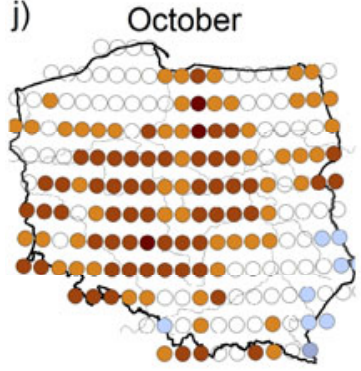

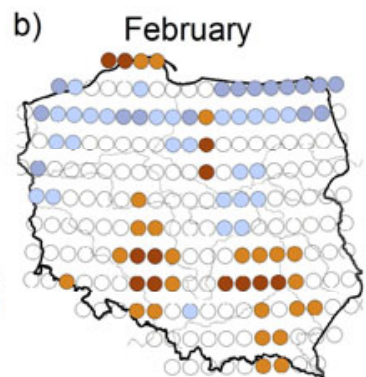

e)

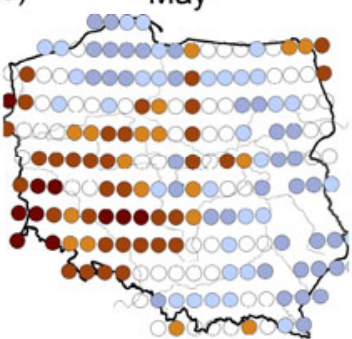

h)

August

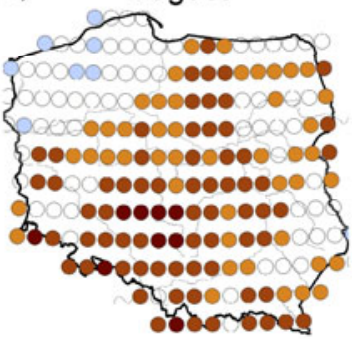

k) November

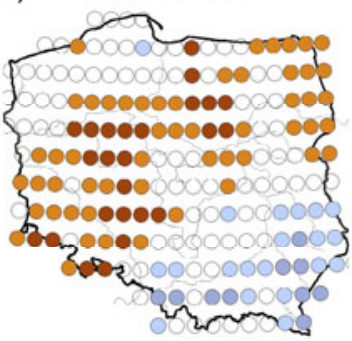

c) March

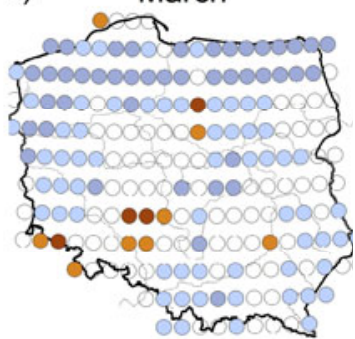

f)

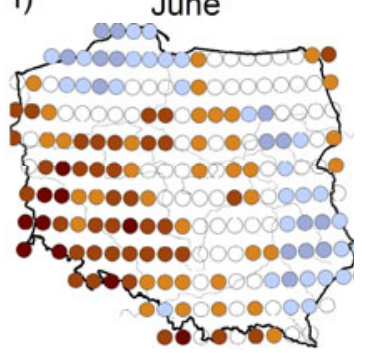

i) September

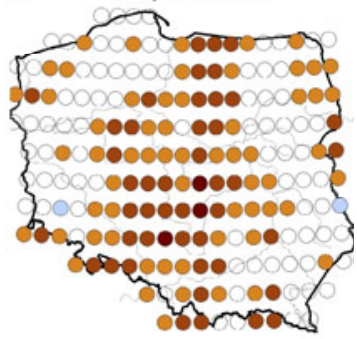

I) December

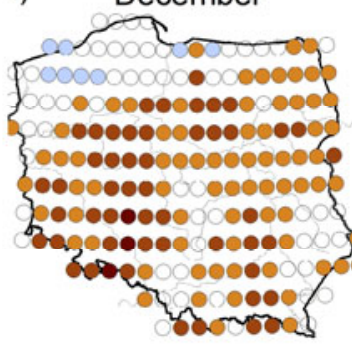

Kendall-Theil robust line slope

$$
\begin{array}{llll}
- & -0.0372--0.020 & \circ & -0.0049-0.005 \\
- & -0.0199--0.010 & \circ & 0.0049-0.010 \\
- & -0.0099--0.005 & \circ & 0.0101-0.020
\end{array}
$$

Fig. 6. Rate of change of the SPEI-3 values over Poland in the years 1956-2015, evaluated by the Kendall-Theil robust line method. 
a)

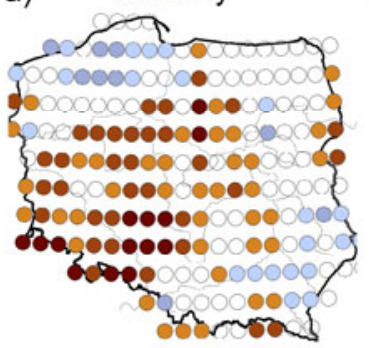

d)

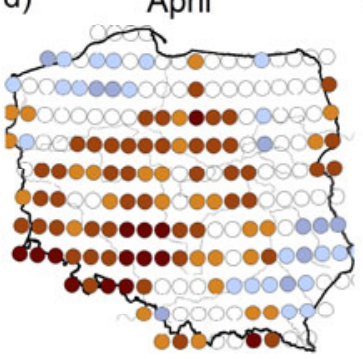

g)

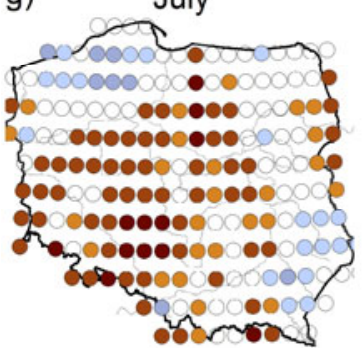

j)

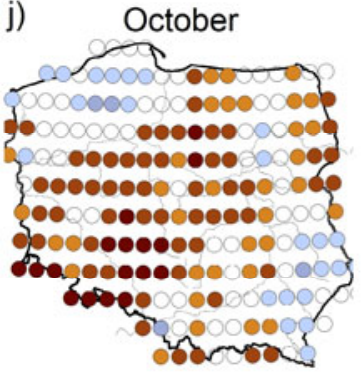

b)

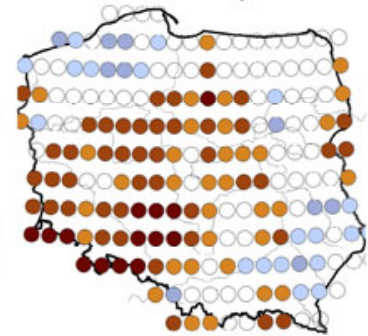

e)

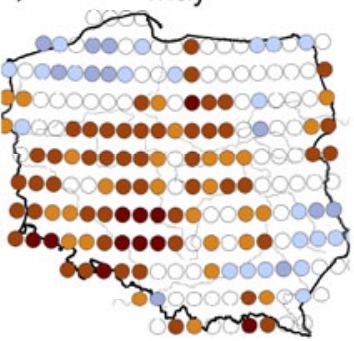

h)

August

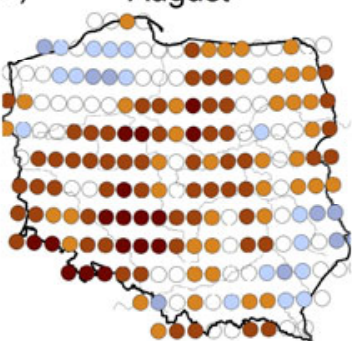

k) November

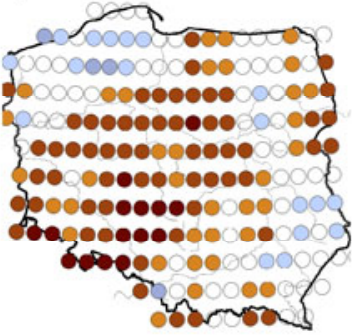

c) March

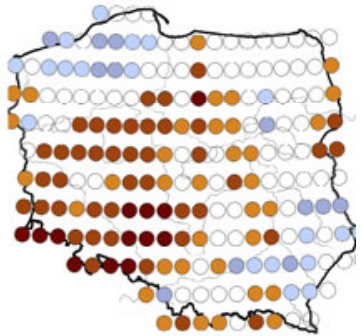

f) June

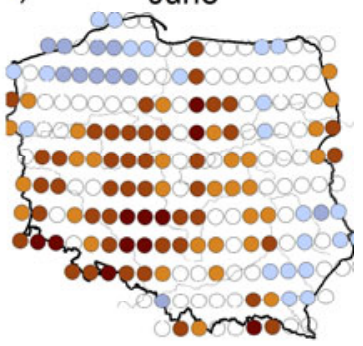

i) September

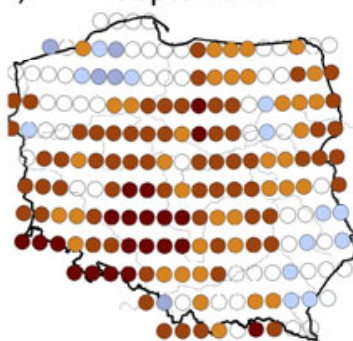

I) December

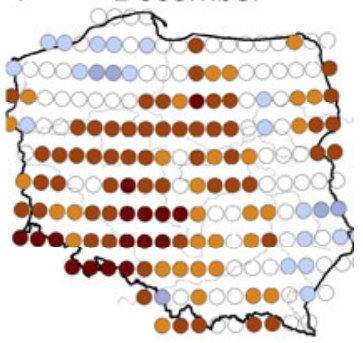

Kendall-Theil robust line slope

$$
\begin{array}{llll}
- & -0.0372--0.020 & \circ & -0.0049-0.005 \\
\text { - } & -0.0199--0.010 & \circ & 0.0051-0.010 \\
- & -0.0099--0.005 & \circ & 0.0101-0.020
\end{array}
$$

Fig. 7. Rate of change of the SPEI-12 values over Poland in the years 1956-2015, evaluated by the Kendall-Theil robust line method. 
The spatial pattern of grid cells with decreasing (drying) trend extends from the south-west to the center of the country. It is especially visible in April (Fig. 4d), August (Fig. 4h), and October (Fig. 4j), whereas in other months, such a "compact" group of cells does not show up. It is worth mentioning that in May (Fig. 4e) and March (Fig. 4c) an increasing trend is marked, respectively, in the east and north. A much more consolidated group of grid cells with decreasing trends was detected in the monthly SPEI-12 series (Fig. 5). Here, the area affected by a decreasing trend extends from southwest to the central parts of the country, throughout all months. The largest spatial extent of a drying trend occurs in August, September, and October, covering approximately $30-33 \%$ of the territory (Fig. 5h-j, Table 3). An increasing trend concerns selected pixels only. Considering the rate of change of the SPEI over the 60-year period, evaluated by the Kendall-Theil robust line (Figs. 6 and 7), it is worth mentioning that a considerable part of Poland experiences drying signals (negative values of slope of the Kendall-Theil robust line). This concerns approximately 56-64\% of the territory in August, September, and October, both for the 3-month and the 12-month SPEI (Table 3).

The obtained results concerning drying trends over Poland coincide with previously conducted studies, although for different long-term periods. Labędzki et al. (2014) investigated reference evapotranspiration, based on 18 stations across Poland. It was proved that there is an increasing trend in the reference evapotranspiration in 1971-2010, explained by the trends of air temperature and sunshine as the main factors determining evapotranspiration. Simultaneously, it was detected that the reference evapotranspiration pattern across Poland showed differences, with the highest values recorded in central Poland, from west to east, where there is relatively low precipitation, causing significant meteorological and agricultural droughts. The region of the highest increase of reference evapotranspiration, although based only on 18 stations, coincides with the region of statistically significant drying trends of SPEI-3 and SPEI-12, detected in this study. However, the SPEI is considered to be a more complex index in detecting drying trends, including not only evapotranspiration but also precipitation.

\subsection{Changes in the SPEI over the growing season}

In order to check if there is a trend in the SPEI values over the growing season, the SPEI values were averaged over the 6-month period from April to September. Then, the 60 -element series of the SPEI-3 and SPEI-12 were prepared for each grid point and the Mann-Kendall test was performed (Fig. 8a, c). For comparison, the SPEI-6 series for September was investigated, representing the cumulative moisture conditions for the six months of 
a)

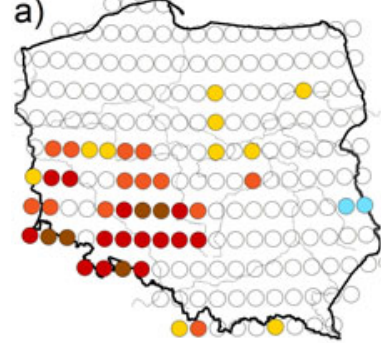

b)

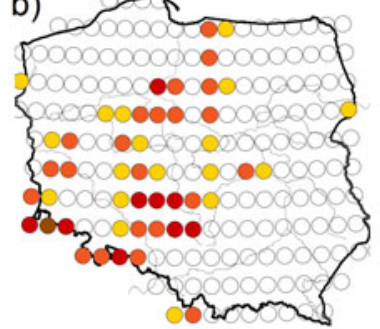

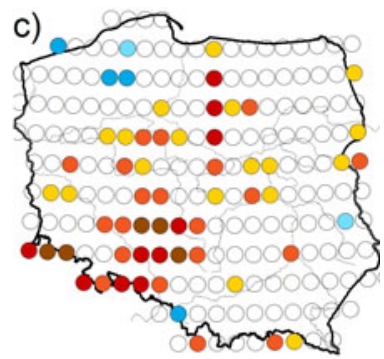

Test Statistic / Significance level (\%)

- $<=-3.290 / 99.9 \%$

(-1.645- 1.645) / not significant

- $(-3.290--2.575] / 99 \%$

- $[1.645-1.960) / 90 \%$

- $(-2.575--1.960] / 95 \%$

- $[1.960-2.575) / 95 \%$

- $(-1.960--1.645] / 90 \%$

- $[2.575-3.290) / 99 \%$

d)

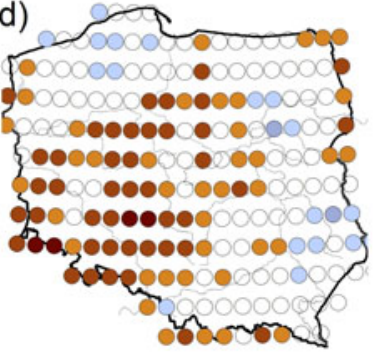

e)

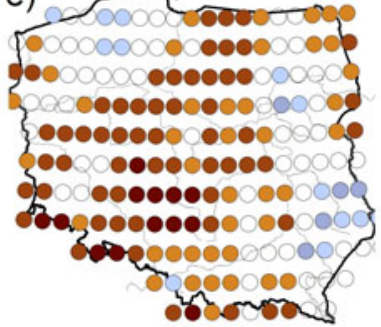

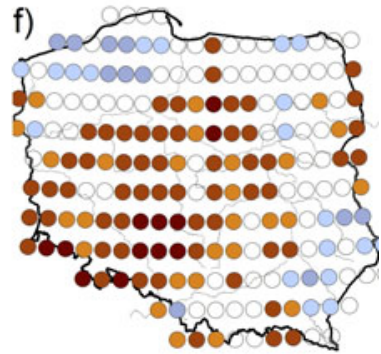

Kendall-Theil robust line slope

- $-0.0372--0.020 \bigcirc-0.0049-0.005$

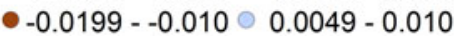

$-0.0099--0.005 \bullet 0.0101-0.020$

Fig. 8. Mann-Kendall test results of trend detection over the growing season (AprilSeptember) for the SPEI-3 (a), SPEI-6 for September (b), and SPEI-12 (c). Rate of change evaluated by the Kendall-Theil robust line slope in the time series of the SPEI-3 (d), SPEI-6 for September (e), and SPEI-12 (f).

the growing season (Fig. 8b). Additionally, the rate of the SPEI change was estimated by the Kendall-Theil robust slope for the respective SPEI time scales (Fig. 8d-f). Drying trends occurred in the region extending from the south-west to the center of the country and over single grid cells in the northeast. The changes of the SPEI values, reflecting the drying, range from $0.03 \mathrm{yr}^{-1}$ to $-0.005 \mathrm{yr}^{-1}$. It is worth mentioning that the spatial extent of a region with drying signals is much wider than that with a drying trend as it includes also these grid cells where there is no trend but the drying tendency is pronounced. The drying trend concerns approximately $21 \%$ of the country for the SPEI-3, 25\% for the SPEI-6 (for September), and 27\% for the SPEI12 (Fig. 8a-c). The drying signals occur on $42 \%$ of the area in the case of SPEI-3, on the $58 \%$ for SPEI-6 (for September), and on the $47 \%$ for SPEI- 12 . 


\section{CONCLUDING REMARKS}

This paper analyzes the extent of the drought-affected area in Poland over the 1956-2015 period and drying trends evaluated by the Standardized Precipitation-Evapotranspiration Index (SPEI). The analysis extends to the year 2015, which was marked as extremely hot and dry. The 3-month, 6-month, and 12-month SPEI values were investigated, representing drought conditions relevant to agriculture and hydrology.

The analysis shows a broad variability in the spatial extent of droughts on the territory of Poland. Drought events of differing severity occur in both the winter and summer halves of the year. The most widespread 3-month extreme summer drought occurred in August 2015, affecting 47\% of the national land area. The most widespread extreme 12-month drought also occurred in August 2015, covering 44\% of the aforesaid area. The percentage of the drought-affected area has witnessed an increase for all three SPEI timescales, albeit with different rates of change. This pertains to both the annual mean of the area under drought as well as to the drought-affected area separately in the summer and winter halves of the year.

A relatively large area of Poland exhibits significant drying trends, extending from the south-west towards the center part of the country and, in some cases, to the north-east. This especially pertains to months in the summer half of the year, as well as to the growing season considered as a whole. The drying trends during the growing season extend to approximately $21 \%$ of the total land area for SPEI-3, 25\% for SPEI-6 (for September), and 27\% for SPEI-12. However, drying signals occur over a much larger percentage of the total area, which amounts to over $40 \%$ in the case of SPEI-3 and SPEI-12, and as much as 58\% in case of SPEI-6. In effect, the results reveal that drying trends or signals on the territory of Poland have affected a substantial area of the country. The year 2015 has witnessed considerably higher-than-normal air temperature and subnormal precipitation, which were reflected by the relatively long period of negative SPEI values.

In conclusion, it is worth noting that prolonged drying trends might have a subsequent negative impact on both the environment and society. As Poland has rather scarce water resources, the preparation of adaptation strategies to counteract climate change through appropriate water programs seems to be a challenging issue.

Acknowledgments. The author expresses her gratitude to the anonymous reviewers for their constructive and helpful remarks and suggestions. 


\section{References}

Beguería, S., S.M. Vicente-Serrano, and M. Angulo-Martinez (2010), A multiscalar global drought dataset: the SPEIbase: a new gridded product for the analysis of drought variability and impacts, Bull. Am. Meteorol. Soc. 91, 13511356, DOI: 10.1175/2010BAMS2988.1.

Beguería, S., S.M. Vicente-Serrano, F. Reig, and B. Latorre (2014), Standardized precipitation evapotranspiration index (SPEI) revisited: parameter fitting, evapotranspiration models, tools, datasets and drought monitoring, Int. J. Climatol. 34, 10, 3001-3023, DOI: 10.1002/joc.3887.

Damberg, L., and A. AghaKouchak (2014), Global trends and patterns of drought from space, Theor. Appl. Climatol. 117, 3, 441-448, DOI: 10.1007/s00704013-1019-5.

Fan, Y., and H. van den Dool (2008), A global monthly land surface air temperature analysis for 1948-present, J. Geophys. Res. 113, D1, D01103, DOI: 10.1029/2007JD008470.

Graczyk, D., and Z.W. Kundzewicz (2014), Changes in thermal extremes in Poland, Acta Geophys. 62, 6, 1435-1449, DOI: 10.2478/s11600-014-0240-7.

Helsel, D.R., and R.M. Hirsch (2002), Statistical Methods in Water Resources, Techniques of Water Resources Investigations, Book 4, Chapter A3, U.S. Geological Survey, 395 pp.

IMGW (2015), Bulletin of the National Hydrological and Meteorological Service, Institute of Meteorology and Water Management (IMGW), State Research Institute, Warsaw, Poland, No. 13, 65 pp.

IUNG-PIB (2015), Communication report regarding the incidences of drought conditions in Poland, period: 13 (1.VIII - 30.IX), Institute of Soil Science and Plant Cultivation - State Research Institute (IUNG-PIB), Puławy, Poland, available from: http://www.susza.iung.pulawy.pl/en/arch15 (accessed: 4 September 2016).

Kędziora, A., M. Kępińska-Kasprzak, P. Kowalczak, Z.W. Kundzewicz, A.T. Miler, E. Pierzgalski, and T. Tokarczyk (2014), Risks resulting from water shortages, Nauka 1, 149-172 (in Polish).

Kundzewicz, Z.W. (2008), Hydrological extremes in the changing world, Folia Geograph. Ser. Geograph. Phys. 39, 37-52.

Lorenc, H., M. Mierkiewicz, and M. Sasim (2008), Drought in Poland with special regards to the year 2006, Wiadomości IMGW 2, 1-2, 3-32 (in Polish).

Łabędzki, L. (2007), Estimation of local drought frequency in Central Poland using the standardized precipitation index SPI, Irrig. Drainage 56, 1, 67-77, DOI: 10.1002/ird.285.

Łabędzki, L., and B. Bąk (2004), Standardized climatic water balance a drought index, Acta Agrophys. 3, 1, 117-124 (in Polish). 
Łabędzki, L., and B. Bąk (2014), Meteorological and agricultural drought indices used in drought monitoring in Poland: a review, Meteorol. Hydrol. Water Manag. 2, 2, 3-14.

Łabędzki, L., B. Bąk, and K. Smarzyńska (2014), Spatio-temporal variability and trends of Penman-Monteith reference evapotranspiration (FAO-56) in 1971-2010 under climatic conditions of Poland, Pol. J. Environ. Stud. 23, 6, 2083-2091.

Machiwal, D., and M.K. Jha (2012), Hydrologic Time Series Analysis: Theory and Practice, Springer, Dordrecht and Capital Publ. Co., New Delhi.

Osuch, M., R.J. Romanowicz, D. Lawrence, and W.K. Wong (2015), Assessment of the influence of bias correction on meteorological drought projections for Poland, Hydrol. Earth Syst. Sci. Discuss. 12, 10331-10377, DOI: 10.5194/ hessd-12-10331-2015.

Potop, V., C. Boroneant,, M. Mozny, P. Stepánek, and P. Skalák (2014), Observed spatiotemporal characteristics of drought on various time scales over the Czech Republic, Theor. Appl. Climatol. 115, 3-4, 563-581, DOI: 10.1007/ s00704-013-0908-y.

Radziejewski, M., and Z.W. Kundzewicz (2004a), Detectability of changes in hydrological records, Hydrol. Sci. J. 49, 1, 39-51, DOI: 10.1623/hysj.49.1. 39.54002 .

Radziejewski, M., and Z.W. Kundzewicz (2004b), Development, use and application of the HYDROSPECT data analysis system for the detection of changes in hydrological time-series for use in WCP - Water and National Hydrological Services, WCASP-65, Hydrospect, Version 2.0, User's manual, WMO, Geneva, Switzerland.

Radzka, E. (2015), The assessment of atmoshperic drought during vegetation season (according to standardized precipitation index SPI) in central-eastern Poland, J. Ecolog. Eng. 16, 1, 87-91.

Spinoni, J., G. Naumann, and J. Vogt (2015), Spatial patterns of European droughts under a moderate emission scenario, Adv. Sci. Res. 12, 179-186, DOI: 10.5194/asr-12-179-2015.

Stagge, J.H., L.M. Tallaksen, C.-Y. Xu, and H.A.J. van Lanen (2014), Standardized precipitation-evapotranspiration index (SPEI): Sensitivity to potential evapotranspiration model and parameters. In: Proc. FRIEND-Water 2014, IAHS Red Book, 363, Montpellier, France.

Szwed, M., G. Karg, I. Pińskwar, M. Radziejewski, D. Graczyk, A. Kędziora, and Z.W. Kundzewicz (2010), Climate change and its effect on agriculture, water resources and human health sectors in Poland, Nat. Hazards Earth Syst. Sci. 10, 8, 1725-1737, DOI: 10.5194/nhess-10-1725-2010.

Theil, H. (1950), A rank-invariant method of linear and polynomial regression analysis, 1, 2, and 3, Proc. R. Neth. Acad. Sci. 53, 386-392, 521-525, $1397-$ 1412, DOI: 10.1007/978-94-011-2546-8_20. 
Thornthwaite, C.W. (1948), An approach towards rational classification of climate, Geograph. Rev. 38, 1, 55-94, DOI: 10.2307/210739.

Tokarczyk, T. (2013), Classification of low flow and hydrological drought for a river basin, Acta Geophys. 61, 2, 404-421, DOI: 10.2478/s11600-012-0082-0.

Vicente-Serrano, S.M., S. Begueria, and J.I. Lopez-Moreno (2010), A multiscalar drought index sensitive to global warming: the standardized precipitation evapotranspiration index, J. Climate 23, 7, 1696-1718, DOI: 10.1175/ 2009JCLI2909.1.

Wang, J., Y. Sheng, and T.S.D. Tong (2014), Monitoring decadal lake dynamics across the Yangtze Basin downstream of Three Gorges Dam, Remote Sens. Environ. 152, 251-269, DOI: 10.1016/j.rse.2014.06.004.

Wibig, J. (2012), Moisture conditions in Poland in view of the SPEI index, WodaŚrodowisko-Obszary Wiejskie 12, 2, 38, 329-340 (in Polish).

WMO (2012), Standardized Precipitation Index. User Guide, WMO No. 01090, World Meteorological Organization, Geneva, Switzerland.

Zargar, A., R. Sadiq, B. Naser, and F.I. Khan (2011), A review of drought indices, Environ. Rev. 19, NA, 333-349, DOI: 10.1139/a11-013.

Zhang, K., J.S. Kimball, R.R. Nemani, S.W. Running, Y. Hong, J.J. Gourley, and Z. B. Yu (2015), Vegetation greening and climate change promote multidecadal rises of global land evapotranspiration, Nat. Sci. Rep. 5, 15956, DOI: $10.1038 /$ srep 15956.

Ziese, M., A. Becker, P. Finger, A. Meyer-Christoffer, B. Rudolf, and A. Schneider (2011), GPCC First Guess Product at 1.0: Near real-time first guess monthly land-surface precipitation from rain-gauges based on SYNOP data, DOI: 10.5676/DWD_GPCC/FG_M_100.

Ziese, M., U. Schneider, A. Meyer-Christoffer, K. Schamm, J. Vido, P. Finger, P. Bissolli, S. Pietzsch, and A. Becker (2014), The GPCC Drought Index a new, combined and gridded global drought index, Earth Syst. Sci. Data 6, 2, 285-295, DOI: 10.5194/essd-6-285-2014.

Received 29 March 2016 Received in revised form 4 September 2016 Accepted 7 September 2016 